\title{
Abbreviations for Kafka Citations
}

The following abbreviations are used throughout the text and notes, followed by the appropriate page numbers.

A Amerika: A Novel, trans. Edwin and Willa Muir. New York: Schocken, 1962. See R.

B Beschreibung eines Kampfes, ed. Max Brod. Frankfurt am Main: Fischer, 1954. See DS and GW.

BF Briefe an Felice, ed. Erich Heller and Jürgen Born. Frankfurt am Main: Fischer, 1967. See LF.

BM Briefe am Milena, ed. Willi Haas. New York: Schocken, I952. See LM.

$\mathrm{Br}$ Briefe, 1902-1924, ed. Max Brod. Frankfurt am Main: Fischer, I958. See L.

C The Castle, trans. Willa and Edwin Muir. Harmondsworth, Middlesex: Penguin, 1966. See R.

DI The Diaries of Franz Kafka, 1910-1913, trans. Joseph Kresh. New York: Schocken, I948. See Ta.

DII The Diaries of Franz Kafka, 1914-1923, trans. Martin Greenberg. New York: Schocken, 1949. See Ta.

DF Dearest Father, trans. Ernst Kaiser and Eithne Wilkins. New York: Schocken, I954. See H.

DS Description of a Struggle, trans. Tania and James Stern. New York: Schocken, 1958. See B. 
E Erzählungen, ed. Max Brod, Frankfurt am Main: Fischer, 1946. See $\mathrm{S}$.

GW The Great Wall of China, trans. Willa and Edwin Muir. New York: Schocken, I960.

$\mathrm{H} \quad$ Hochzeitsvorbereitungen auf dem Lande und andere Prosa aus dem Nachla $\beta$, ed. Max Brod. Frankfurt am Main: Fischer, 1953. See DF.

J Gustav Janouch, Conversations with Kafka, trans. Goronwy Rees. New York: New Directions, I97I.

L Letters to Friends, Family, and Editors, trans. Richard and Clara Winston. New York: Schocken, 1977. See Br.

LF Letters to Felice, trans. James Stern and Elizabeth Duckworth. New York: Schocken, 1973. See BF.

LM Letters to Milena, ed. Willi Haas, trans. Tania and James Stern. New York: Schocken, I953. See BM.

M The Metamorphosis, ed. and trans. Stanley Corngold. New York: Bantam Books, 1972. See E.

PP Parables and Paradoxes. German and English. New York: Schocken, I96I.

R Die Romane: Amerika, Der Proze $\beta$, Das Schlo $\beta$. Frankfurt am Main: Fischer, 1972.

S The Complete Stories, ed. Nahum Glatzer. New York: Schocken, I 97 I. See E.

SE Sämtliche Erzählungen, ed. Paul Raabe. Frankfurt am Main: Fischer, I970.

$\mathrm{T}$ The Trial, trans. Willa and Edwin Muir. New York: Modern Library, 1956. See R.

Ta Tagebücher, ed. Max Brod. Frankfurt am Main: Fischer, I95I. See DI, DII. 


\section{Franz Kafka}

The Necessity of Form 
